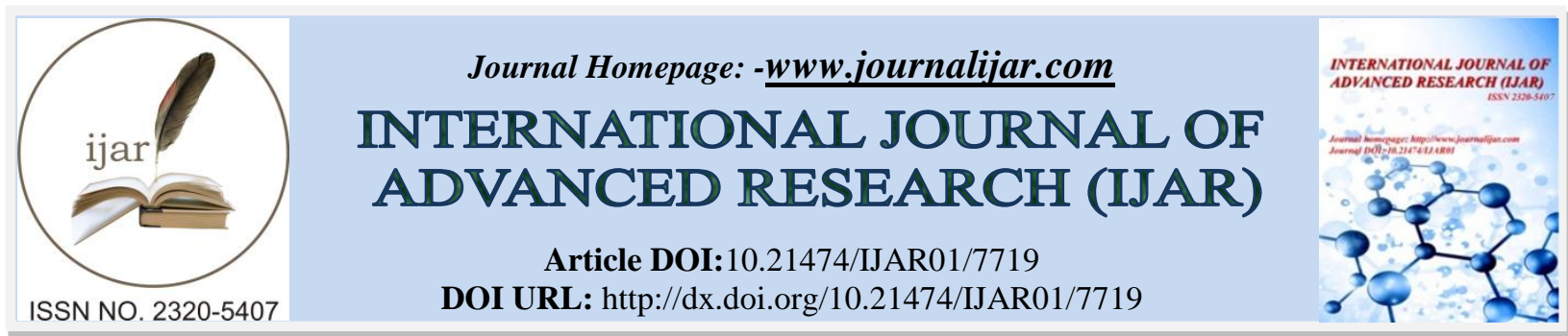

RESEARCH ARTICLE

\title{
REFLECTION OF CHILDREN LEARNING A FOREIGN LANGUAGE AND LANGUAGE LEARNT ON THE LINGUISTIC INTERACTION WITHIN THE FAMILY.
}

\author{
Yusuf şahin. \\ GiresunÜniversitesi, Yabancı Diller Yüksekokulu, GüreYerleşkesi, Giresun-Türkiye.
}

\section{Manuscript Info}

Manuscript History

Received: 21 July 2018

Final Accepted: 27 August 2018

Published: September 2018

Keywords:-

Foreign language teaching to young learners, foreign language learning strategies, motivation, learning and teaching, linguistic interaction.

\begin{abstract}
In this study, foreign language learning motivation of children at the ages of 6-9, manner of implementation of the things learnt, and the reflection of children's foreign language learning on communication within the family were analyzed. The learning content of the course organized for children was prepared by synthesizing the principles of "Symbolic Interaction Theory" and "Social Interaction Theory" with considering the development levels of the students.

The study was conducted on the parents of students attending to the "Foreign Language for Young Learners" course organized by a State University, School of Foreign Languages. Students who participated into the study were divided into two groups: those who haven't started to the primary education yet in the first group, and primary school students in the second group.

The data of the study were obtained through a questionnaire prepared for the parents. When the data were analyzed it was identified that children's eagerness to learn a language was quite high depending on the learning environment created and the methods applied, children developed several learning strategies to implement what they learnt, they showed behaviors of teaching to the family members and encouraging them to learn as well as showing what they learnt while communicating with their parents. Also, parents expressed their desire to learn a language in order to support their children in foreign language learning.
\end{abstract}

Copy Right, IJAR, 2018,. All rights reserved.

\section{Introduction:-}

Learning is the structuring process where the individual is mentally active. Individuals organize their experiences gained to adapt to the environment in the cognitive structures corresponding to each experiences from the moment they are born. The depth and functionality of the generated cognitive structures are parallel with whether these structures make the individual's life sustainable and how enjoyable they are.

The relationship between learning and sustainability of life can be explained by using the knowledge the individuals gain as a result of their experience to overcome all kinds of physical and psychological obstacles that threaten or complicate their lives. The process of adapting to the environment beginning with the efforts to meet basic physical requirements, acquires a bi-directional character by the emergence of the psychological requirements that are shaped by the establishment and execution of interpersonal relations as a necessity of being a social being as well as the 
fulfillment level of primary physical needs. While the fulfillment of children's physical needs ensures the continuation of their existence, the fulfillment of their cognitive and affective needs determines the position of the individual as a social being in the society. At every stage of education for children, the responsible people are obliged to create a learning environment that contributes to the growth of the children as individuals who can rule over their body, mind and emotions (Adıgüzel, 2009; DoğanayveTok, 2010).

In the light of the information given so far, where to start and how to continue to "teach foreign language to children", which sets the primary goal of this study, will be tried to be elucidated.

\section{Basics Of Foreign Language Teaching To Children}

Foreign language instruction carried out in educational institutions is conducted on the basis of certain principles. "Symbolic Interaction Theory" which sees communication as a process of decoding the symbols created on consensus, and "Social Interaction Theory - Socio-cultural Theory" which highlights the interpersonal sharing of social achievements emphasize the principles that form the basis of language learning. Curriculum development studies for foreign language teaching benefit from the main ideas in these two theories.

\section{Symbolic Interaction Theory}

The theory arguing that individuals recognize, understand, comprehend and interpret the environment they live in based on symbols is developed by George Herbert Mead. According to this theory, our behaviors are guided by the symbols we infer from what happens in our environment (Poloma, M. 1993). Symbols with communicative function are classified as linguistic and non-linguistic symbols. Linguistic symbols are words and their usages appropriate to the situation; non-linguistic symbols are beings on which symbolic value is attributed, signs, gestures, and mimics which have communicative functions. Linguistic and non-linguistic symbols do not appear independently from one another both in native language acquisition and foreign language teaching. Word-behavior, word-object, wordsituation are mutually complementary objects.

\section{Social Interaction Theory - Socio-cultural Theory}

Social Interaction Theory bases language learning on the linguistic interaction that people, as social beings, create with the individuals in their environment. The principles related to teaching and learning stated by this theory which was developed from Vygotsky's ideas are:

- Learning and cognitive development are social and collaborative activities.

- In the planning and presentation of the contents to be taught to the individual, the individual's overall development zones and steps (Zone of Proximal Development) are taken into account.

- The content is presented as meaningful wholes, addressing the real life space of the individual.

- The learning environment and the real life space complement each other (Berger, K. S. and Thompson, R. A. 1995; Rogof, B. and Morelli, G. 1989).

The source of the concepts, ideas, phenomena, skills, and attitudes acquired by individuals is the social environment they are in. People children interact with and social environment play a decisive role in the cognitive development of the children. The frequency and nature of the relationship established between the children and adults or their peers determine the direction of their cognitive development. Language is the most effective tool at this point. Teacher behaviors and language used in the teaching process should contribute to the increase in children's eagerness for learning, internalization of what is learnt, independent thinking, and finding different solutions to a problem. The tools used in teaching should facilitate learning and enhance the permanence of learning.

\section{Why are foreign languages taught to children?}

Education, in the shortest sense, is to prepare the individual for life. It is clear that multilingual, multicultural individuals will be in an advantageous position in the future when developments in the world are carefully monitored. Besides, learning a foreign language means "I want to understand you and tell myself to you". Knowing a foreign language will play an important role in removing the barriers of lack of communication and intolerance underlying the social problems of today's world. A person learning a foreign language will realize the difference and understand that this difference is not an oddity. Foreign language teaching is to make people realize that there are people who think different from us, express what they think differently from us, and live differently depending on their living conditions. Brett (2004) mentions that there are seven hundred different reasons for foreign language learning. 


\section{The Method and Approach in Foreign Language Teaching to Children}

Adults learn foreign languages with an expectation. The expectations of children from a foreign language are, on the other hand, just like it is expected from a game. Just as children do not want to continue a game they do not enjoy, or they do not want to play it again, foreign language teaching to children should be considered as a delightful game.

In the beginning, it will be necessary to create an affective and kinetic learning environment in which children can learn entertainingly based on the concrete means and behaviors they often see in their surroundings, since addressing children's cognitive domain is not a proper way. At first, Total Physical Response Method can be used as the teaching method; teaching with games and songs, drama and demonstration/application can be used as teaching techniques; and living/non-living creatures, pictures, posters, models, puppets, short films with visual and auditory aids, short stories and jokes, puzzles, all kinds of tools addressing to a child's world in short can be used as course materials (Butzkam, W. and Butzkam, J., 2004; Demirel, 2003; Gibitz, 2002; Kühne, 2003; Memiş and Erdem, 2013; Weimer, 2002).

The persistence and sustainability of learning is closely related to the level of the knowledge and behavior learnt meet interests and needs of the individual. What the beings in the outer world surrounding the individual are (naming) and knowing what they serve (function) are decisive factors for the individuals to become aware of their own positions. In the next step, attitudes and behaviors formed as a result of the effects of these beings on the individuals and the relationships of the individuals with them (interaction) provide a basis for the diversification of the needs (cognitive-affective and kinetic). The ways of teaching a foreign language to children are:

\section{Studying with real objects:}

As they appeal to the multiple sensory organs of a child, real objects provide a convenient learning environment (Akpınar and Aydın, 2009).

Fig. 1:-Example images
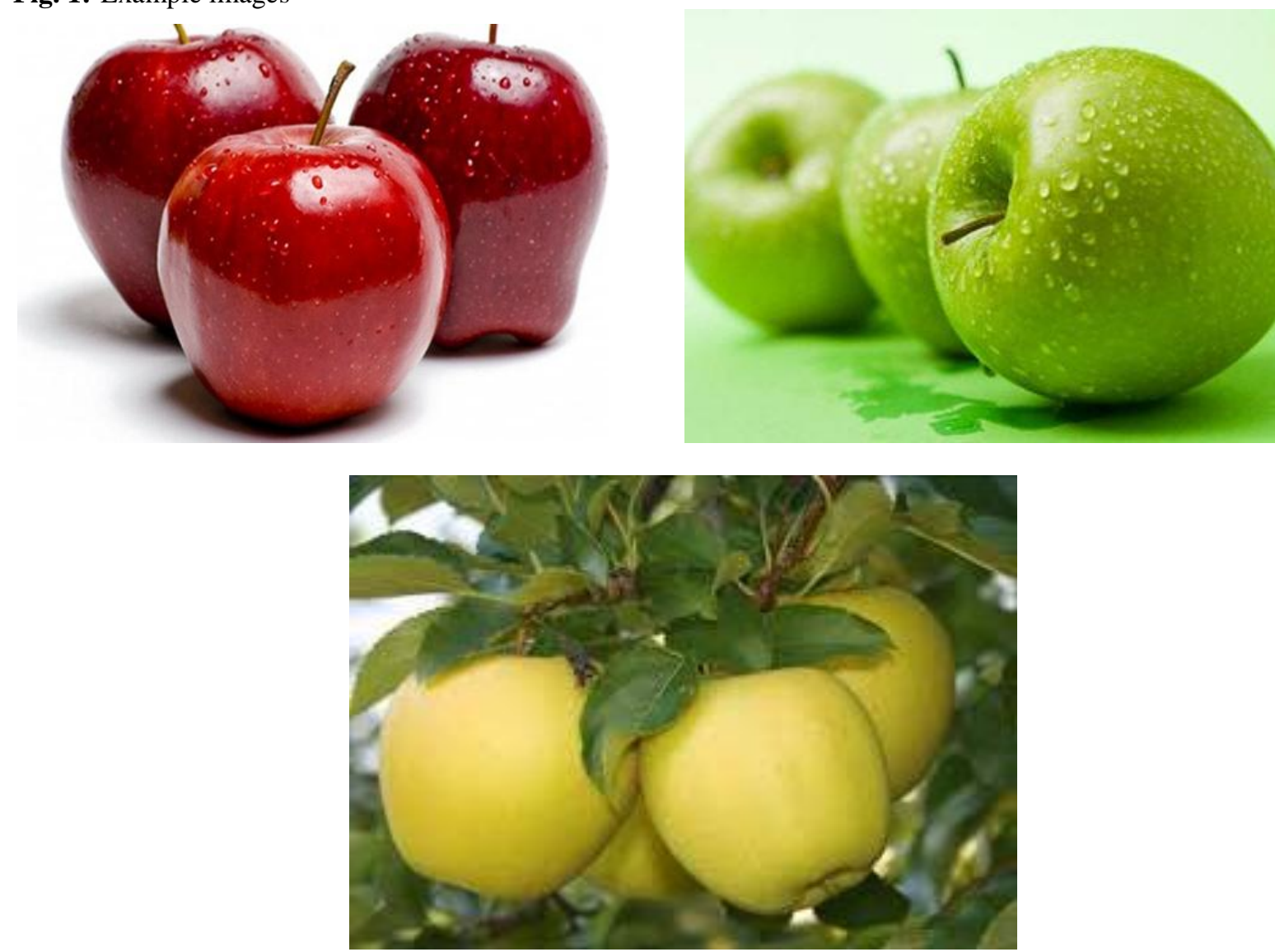

Source: www.bilgihanem.com 
In the example shown above, the children learn the name, shape, color and taste of the food presented to them.

Apple: round, red, yellow, green

Red apple, green apple, yellow apple

Gets the taste of the food (liking or disliking),

Apple: sweet, sour

Sweet apple, sour apple

If the children like it, they will desire and develop a positive attitude; if they do not like it, they will develop a negative attitude and alienate from it. As both leave traces in the individuals, they both contribute positively to learning.

I liked the apple. I enjoyed it. I like apples.

I did not like the apple. I didn't enjoy it. I do not like apples.

Who presents the food to the child and how the food is presented determine the form and maintenance of the relations between people. The attitude and behavior children will develop against a person who approaches them generously and lovingly increase the desire of the children to be ready to receive any information and behavior from that person. That's why it is the primary condition that the people to be employed in foreign language teaching to children should be those who are trained in the fields of child psychology and psychology of learning (Anşin, 2006). Selection and presentation of the content in foreign language teaching to children should be planned to address the world of children (Lightbown\&Spada, 2006; Wesche\&Skehan, 2002; Nunan, 2001; Richards, J. C., Rodgers, T. S., 2001). With reference to the principle of known to unknown in teaching, education starts with naming the concrete objects around the children, their features and functions. Although games are means of entertainment for adults, they are important learning environments for children and they should be taken seriously, because children both entertain and take games serious. At the same time, colors, numbers, birthdays, seasons, celebrations, food types, mealtimes, favorite items, toys, clothes, parts of the body, and family members are some of the areas that can be chosen as subjects for language teaching to children. Verbs and adjectives we use frequently in everyday life can be taught with plenty of examples, games and songs (Lee,1979; Maurice,1988).

\section{Language Teaching through Images}

Images are used in cases where real objects cannot be brought into classroom or where experienced situations cannot be reflected in the classroom. Students involve in the activities conducted through images more than in the activities performed only through written texts (Demircan, 2005:199).

Fig. 2:-Images illustrating real-life objects

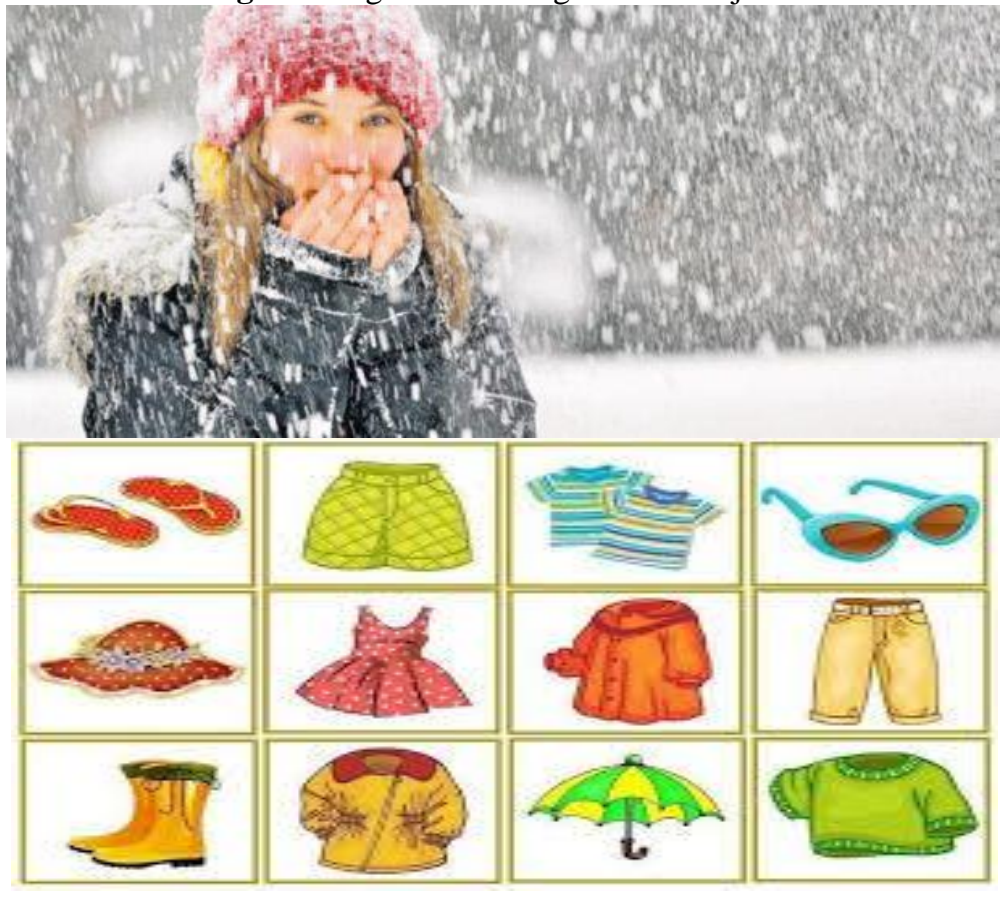


As children learn holistically, it is necessary to incorporate all sense organs into learning. It is needed to create an environment where the children can learn by hearing, smelling, testing, touching, seeing, talking, cheering, and laughing. What is to be remembered here is to ensure that children enjoy while learning the new language and to create a natural environment in which they will learn without being under the pressure of success. The main goal is to make them understand what they hear and express themselves verbally even if it is simple. Singing together and memorizing songs which include items from daily life and are supported with images can make learning more enjoyable (Maurice, 1988). At the same time, the use of bodily movements appropriate to the content of the song along with the song will make learning meaningful.

\section{The Purpose of the Study}

The purpose of this study is to examine the behaviors of children in learning a foreign language other than their first language and the effects of forms of linguistic interaction that is observed in the relations established with their environment on their parents.

\section{Method:-}

The study was conducted on four groups of children, two pre-school groups and two primary school groups, each with 10 trainees. The data of the study were obtained by means of the written answers given by the parents of the children learning a foreign language to a 7-question data collection tool prepared by the researcher. Questionnaire is a systematic data gathering technique by posing questions about a specific topic to the individuals comprising the research population or sample (Balc1, 2005; Karasar, 2003). The obtained data were collected in two groups as preschool children and primary school children, data of each group was firstly interpreted in itself, and then the groups were compared.

\section{Findings}

Answers given by the parents to the question "what is your reason for asking your children to learn a foreign language?":

Table 1:-Foreign language learning reasons for children

\begin{tabular}{|c|c|c|c|c|}
\hline \multirow[t]{2}{*}{ Reasons } & \multicolumn{2}{|c|}{$\begin{array}{r}\text { Preschool } \\
\text { Children(20) }\end{array}$} & \multicolumn{2}{|c|}{ Primary School Students(20) } \\
\hline & $\mathbf{f}$ & $\%$ & $\mathbf{f}$ & $\%$ \\
\hline To broaden their horizon & 6 & .30 & 14 & .70 \\
\hline To prepare for the future & 20 & .100 & 20 & .100 \\
\hline To access to a variety of information sources & 3 & .15 & 18 & .90 \\
\hline To get better job opportunities in the future & 19 & .95 & 16 & .80 \\
\hline To communicate with foreigners & 14 & .70 & 9 & .45 \\
\hline $\begin{array}{l}\text { The Ministry of Education included foreign language } \\
\text { into the curriculum of second grade. (?) }\end{array}$ & - & - & 2 & .10 \\
\hline $\begin{array}{l}\text { The earlier foreign language learning starts, the better } \\
\text { the children learn the language. }\end{array}$ & 17 & .85 & 12 & .60 \\
\hline To support foreign language courses at school & - & - & 8 & .40 \\
\hline $\begin{array}{l}\text { To complete the missing parts in foreign language } \\
\text { courses }\end{array}$ & - & - & 13 & .65 \\
\hline
\end{tabular}

When the answers are analyzed as preschool children and children going to school;

It can be seen that the answers of the parents of preschool children focus on preparing children for the future, while the responses of the parents of children going to school are mostly about supporting the foreign language courses at school and making up the missing parts.

(?)- It is thought-provoking to show "necessity" as the reason for children's learning foreign language.

Answers given by the parents when their children's willingness to learn a foreign language is asked: 
Table 2:-Children's willingness to learn a foreign language

\begin{tabular}{|c|c|c|c|c|}
\hline \multirow[t]{2}{*}{ Willingness } & \multicolumn{2}{|c|}{$\begin{array}{r}\text { Preschool } \\
\text { Children(20) }\end{array}$} & \multicolumn{2}{|c|}{$\begin{array}{l}\text { Primary School } \\
\text { Students(20) }\end{array}$} \\
\hline & $f$ & $\%$ & $f$ & $\%$ \\
\hline $\begin{array}{l}\text { - They want to learn foreign language very much and come } \\
\text { to the lessons willingly. Their desire increases as they } \\
\text { learn. They never want to miss the course lessons. }\end{array}$ & 20 & .100 & 17 & .85 \\
\hline $\begin{array}{l}\text { - Their desire to learn a foreign language is not much, but } \\
\text { we try to increase their willingness by supporting them. }\end{array}$ & - & - & 3 & .15 \\
\hline $\begin{array}{l}\text { - They were not very willing in the beginning, but as the } \\
\text { course progressed, they began to like it. }\end{array}$ & - & - & 1 & .05 \\
\hline $\begin{array}{l}\text { - They do not show much interest in other school subjects } \\
\text { either. }\end{array}$ & - & - & 2 & .10 \\
\hline
\end{tabular}

It is understood from the answers given by the parents that the vast majority of the children have a high level of eagerness to learn a language and they participate to the courses willingly. It is understood from the parents' statements that a small number of children going to school (10\%) attend the course not by their own desire but due to their parents' request, and that these children do not show interest in the courses just as they do not in the school subjects.

Answers to the question "What are the first behaviors and words of your children when they come home from the foreign language course?":

Table 3:-Children's first behaviors and words when they come home from the foreign language course

\begin{tabular}{|l|l|}
\hline Preschool Children & Primary School Children \\
\hline $\begin{array}{l}\text { - They try to teach us the new words they learn } \\
\text { excitedly. }\end{array}$ & $\begin{array}{l}\text { - They make comparisons with what they have learnt at } \\
\text { school. (generally pronunciation) }\end{array}$ \\
\hline $\begin{array}{l}\text { - They call us using foreign language expressions } \\
\text { instead of saying mother-father in their first language. }\end{array}$ & $\begin{array}{l}\text { - They compare the teacher at the course with their school } \\
\text { teacher. }\end{array}$ \\
\hline - They greet and say goodbye in foreign language. & $\begin{array}{l}\text { - They say that the course is more fun and they learn better } \\
\text { at the course. }\end{array}$ \\
\hline $\begin{array}{l}\text { - They form sentences mixing their first language and } \\
\text { foreign language. }\end{array}$ & $\begin{array}{l}\text { - They find activities about the language they are learning } \\
\text { on the computer. }\end{array}$ \\
\hline $\begin{array}{l}\text {-They ask us questions and test us with what they } \\
\text { have learnt. }\end{array}$ & $\begin{array}{l}- \text { They say they get very tired at the course. They do not } \\
\text { share information about the course with us (f }=3 \%=.15) . \\
(?)\end{array}$ \\
\hline - They try to teach us the songs they memorize. & \\
\hline
\end{tabular}

It is understood that especially pre-school children are very enthusiastic about sharing their first experiences related to foreign language, and that they add new dimensions to the interactions within the family through the words they use and their behaviors. It is seen that the children going to school compare the course environment to the school and develop positive opinions and attitude towards the course environment.

(?) -3 of the children going to school stated that they get very tired and they did not share any information about the course.

Answers by the parents when the behavioral changes observed in their children after starting the foreign language course is asked:

Table 4:-Behavioral changes observed in children after starting the foreign language course

\begin{tabular}{|l|l|}
\hline Preschool Children & Primary School Children \\
\hline $\begin{array}{l}\text { - They have started to tell the names of } \\
\text { the goods and things in the foreign } \\
\text { language. }\end{array}$ & $\begin{array}{l}\text { - They have begun to love the foreign language classes more. Their } \\
\text { confidence in foreign language increased. }\end{array}$ \\
\hline $\begin{array}{l}\text { - They make comparisons between their } \\
\text { first language and the foreign language. }\end{array}$ & - They say that they understand the foreign language classes better. \\
\hline - They use foreign words while speaking & - They say that they participate in the classes more. \\
\hline
\end{tabular}




\begin{tabular}{|l|l|}
\hline their first language. & \\
\hline $\begin{array}{l}\text { - They expect us to respond in the } \\
\text { foreign language. }\end{array}$ & $\begin{array}{l}\text { - They say that they have got higher grades in foreign language exams } \\
\text { and have been rewarded by their teachers. }\end{array}$ \\
\cline { 2 - 2 } & - They do their foreign language homework without help. \\
\cline { 2 - 2 } & - They play computer games in the foreign language. \\
\hline & - They want to speak foreign language at home and with their friends. \\
\hline & -Their desire to learn the things they do not know has increased. \\
\cline { 2 - 2 } & -They want to be English teachers. \\
\hline
\end{tabular}

While the effort to make the difference felt is observed in pre-school children, it is understood that self-confidence of the children going to school have increased by reinforcing the things previously learnt, completing the missing parts, and new things learnt. It can be said that the method and approach applied in the course has a positive effect on the foreign language learning of the children.

Do you do activities at home that can help the children learn a foreign language?

Table 5:-Activities of the parents that contribute to foreign language learning of the children

\begin{tabular}{|c|c|}
\hline Preschool Children & Primary School Children \\
\hline $\begin{array}{l}\text { - We study by cards with images. We look at the images } \\
\text { and tell the foreign language equivalents. }\end{array}$ & $\begin{array}{l}\text { - We study together on the websites specified by the } \\
\text { course teacher. }\end{array}$ \\
\hline $\begin{array}{l}\text { - We find audio sites on the Internet and study } \\
\text { vocabulary and pronunciation. }\end{array}$ & - We make them solve multiple-choice tests (?) \\
\hline - We repeat the things they learnt in the course together. & $\begin{array}{l}\text { - We prepared a vocabulary box. We pick up words } \\
\text { from the box by turns and hear the word in English and } \\
\text { try to find out the meaning. }\end{array}$ \\
\hline - We set up simple sentences in the foreign language. & $\begin{array}{l}\text { - They play the game of telling a day of them in English } \\
\text { with their brothers and sisters. }\end{array}$ \\
\hline - We make them memorize new words. & $\begin{array}{l}\text { - We tell a word or a sentence in English and ask them } \\
\text { to tell the English equivalent. }\end{array}$ \\
\hline - We play English-Turkish vocabulary games at home. & - We try to chat with them in English. \\
\hline $\begin{array}{l}\text { - They practice with their brothers studying at high } \\
\text { school. }\end{array}$ & - We make them learn ten new words each day. \\
\hline - We play cut-and-paste games. & $\begin{array}{l}\text { - We watch movies with English subtitles at home. We } \\
\text { search for the words they do not know on the Internet. }\end{array}$ \\
\hline $\begin{array}{l}\text { - They speak English with their father who knows } \\
\text { English. }\end{array}$ & - We speak only English a day in a week at home. \\
\hline - We watch cartoons in the foreign language. & - We watch cartoons in the foreign language. \\
\hline $\begin{array}{l}\text { - We study together from the foreign language book } \\
\text { prepared for children. }\end{array}$ & $\begin{array}{l}\text { - They have started to translate in English on the } \\
\text { Internet. }\end{array}$ \\
\hline & $\begin{array}{l}\text { - We listen to foreign music and watch foreign videos } \\
\text { on the computer. }\end{array}$ \\
\hline & $\begin{array}{l}\text { - We prepare English project assignments given by their } \\
\text { teachers together. }\end{array}$ \\
\hline
\end{tabular}

It is understood that there are verbal and behavioral changes caused by foreign language learning in the inter-family interactions of both pre-school children and children going to school. It can be said that this change will affect the children's language learning positively and contribute to the increase in the amount of time the parents spend with their children, which in turn strengthens the family ties. However, $25 \%$ of the parents stated that they did not do any activities that would contribute to their children's language learning at home. It can be said that this is directly related to the structure, education, psycho-social situation, and the occupational and financial conditions of the family. As this study is limited to the linguistic interactions of children learning foreign languages, it is considered appropriate to conduct a further study on this topic.

(?) - It is understood that parents who make their children solve multiple-choice tests assess language learning as an activity focused on quantitative success rather than as an activity where the individual gains social and cognitive 
skills. Language learning is the activity of acquiring communicative skills. This may bring academic success, but academic success does not always bring communicative skills.

What are the effects of your children's learning a foreign language on you?

Table 6:-Effects of children learning a foreign language on parents

\begin{tabular}{|c|c|}
\hline Preschool Children & Primary School Children \\
\hline $\begin{array}{l}\text { - It makes us happy that our children are learning foreign } \\
\text { languages. }\end{array}$ & 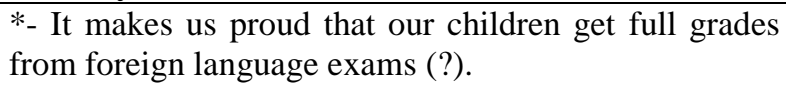 \\
\hline $\begin{array}{l}\text { - We are happy that our children try to teach us foreign } \\
\text { language. }\end{array}$ & $\begin{array}{l}\text {-* They do not get help from us while doing foreign }^{\text {language homework and preparing for foreign }} \\
\text { language exams any more. }\end{array}$ \\
\hline - We are pleased with every single word they say. & - We learn some words from them as well. \\
\hline - We feel insufficient. We wish we had learnt too. & $\begin{array}{l}\text { - We refresh our foreign language knowledge with our } \\
\text { children. }\end{array}$ \\
\hline $\begin{array}{l}\text { - We think that they will be able to stand on their feet } \\
\text { more easily in the future. }\end{array}$ & - We are more hopeful for the future of our children. \\
\hline $\begin{array}{l}\text { - It makes us happy that our children find and evaluate } \\
\text { these kinds of opportunities that we could not find in the } \\
\text { past. }\end{array}$ & $\begin{array}{l}\text { - We decided to learn a foreign language together with } \\
\text { them. }\end{array}$ \\
\hline - Our concerns for the future of our children decrease. & \multirow[t]{2}{*}{-** There has been no effect $(\% 10) .(?)$} \\
\hline $\begin{array}{l}\text { - We feel excited and happy to see that our children lay } \\
\text { sound basis while we are still struggling with the desire to } \\
\text { learn a foreign language. }\end{array}$ & \\
\hline
\end{tabular}

*(?) - Quantitative success-oriented assessment.

The percentage of parents saying their children's foreign language learning do not have any influence on them is $10 \%$ (4 people). This can be explained by the nature of the relationships within the family.

It is understood from the statements of the parents that they are happy as their children are learning a foreign language, that those who do not speak a foreign language begin to have a desire to learn a foreign language, and that those who speak a foreign language try to brush up their knowledge and improve their foreign language skills. The idea that knowing a foreign language is an important part of carving out a good future is shared.

What are your other opinions about your children's foreign language learning?

Table 7:-Other opinions of parents related to the foreign language learning of their children

\begin{tabular}{|l|l|l|}
\hline Other opinions & $f$ & $\%$ \\
\hline $\begin{array}{l}\text { - I do not think it would be effective to try to teach a foreign language without full education } \\
\text { of the first language. }\end{array}$ & 1 & 2,5 \\
\hline - I would like my child to have a more intensive foreign language education. & 7 & 17,5 \\
\hline - I wish these kinds of courses were continuous. & 23 & 57,5 \\
\hline $\begin{array}{l}\text { - I find it very important that the university organizes such a course; It was very useful for } \\
\text { my child and I want it to be constant. }\end{array}$ & 23 & 57,5 \\
\hline - I would like to have more budget-friendly foreign language courses. & 4 & 10 \\
\hline - I care about that children start learning languages at an early age. & 6 & 15 \\
\hline $\begin{array}{l}\text { - My child's ability to speak a foreign language means taking their place in the multicultural } \\
\text { world. In this respect I think that this course is useful. }\end{array}$ & 17 & 42,5 \\
\hline $\begin{array}{l}\text { - Thanks to the positive impression our child got in the course, their other lessons have also } \\
\text { improved. }\end{array}$ & 5 & 12,5 \\
\hline $\begin{array}{l}\text { - I think that the number of students in the classes at schools should be 10-15 as it is in the } \\
\text { courses. }\end{array}$ & 6 & 15 \\
\hline $\begin{array}{l}\text { - Our children's desire to learn foreign language has increased because language has been } \\
\text { tried to be taught in a fun way in the course. }\end{array}$ & 18 \\
\hline - Those who do not present any opinions & 10 \\
\hline
\end{tabular}


Parents have emphasized the fact that foreign language courses are very beneficial for their children, that foreign language learning should be continuous, and that the number of students in foreign language classes at schools are high. The most important point that needs to be emphasized is that foreign language learning should be carried out continuously. It is thought that education planners should take this into consideration.

\section{Discussion, Conclusion and Recommendations:-}

Foreign language education and teaching at an early age has become increasingly widespread around the world, especially in the USA and EU countries. When the general objectives of foreign language teaching at an early age is analyzed, it is seen that these objectives are directed to the same goals with the results obtained from this study, such as having the individuals take their places in the multilingual, multicultural world, and get them prepared for the future (Stewart, 2005; Eurydice, 2012). Also, it is emphasized in the studies about foreign language teaching at an early age that learning a foreign language at an early age has a positive effect on the general development (Akdoğan, 2004) and cognitive enhancement (Chandler, 2014) of the children and the development of their creative thinking, problem solving and adaptation to different environments skills (Berguno\& Bowler, 2004). Moreover, it is stated that children who study a foreign language tend to develop new perspectives and depth of understanding about the vocabulary and structure of their first language (Cumming-Potvin, Renshaw, \& van Kraayenoord, 2003).

It is emphasized in the researches in the field of education that there is a linear relationship between the quality of learning and learning motivation. Highly motivated students will learn readily, and make any class fun to teach, while unmotivated students will learn very little and generally make teaching painful and frustrating (Ambrose, 2010; Wieman, 2013).

It is understood from the answers given by parents that the vast majority of the children have a high level of eagerness to learn a foreign language and that they attend the courses willingly. On the other hand, it is clear from the statements of the parents that a small number of children going to school $(10 \%)$ participate the course by their parents' request rather than their own desire, and these children are not interested in the courses just as they are not in the school subjects. The most important point here to be elaborated is that parents and tutors should have attitudes and behaviors increasing children's internal motivation when the fact that there is a linear relationship between low internal motivation and success in learning is taken into consideration. Furthermore, the reasons for the children's reluctance to learn should be studied in detail from different perspectives.

It is understood that there are verbal and behavioral changes in the interfamily interactions of both pre-school children and the children going to school brought by foreign language learning. It can be said that, on one hand, this change affects children's language learning positively, and on the other hand, increases the amount of time parents spend with their children, which in turn strengthens the family ties. When the practices of the schools where children at early ages are taught foreign languages are examined, it is seen that family involvement plays an important role. One of these schools "Waldorfschulen" defines family involvement as:

Supporting and educating the family,

Enhancing the communication between home and the educational institution and ensuring the continuity of this communication, and

Incorporating the family into the educational processes and enriching the education with their contributions. It is emphasized in Reggio Emilia, Bank Street and the schools where Project-Based Teaching approach is applied that school, family and society should interoperate (Roopnarine, 2011; Katz, 1994).

In the study, it is understood from the statements of the families that they feel happy as their children are learning a foreign language; those not speaking a foreign language have a desire to learn a language, and those speaking a foreign language have an effort to renew and improve their knowledge.

The sacrifice parents made from their budget and time for their children to learn foreign languages and changes in their usual life styles will bring along changes in social communication patterns. This, on one hand, will help the children to grow up being aware of the existence of multilingual and multicultural world, and on the other hand, will lead parents to get new perspectives in their present intellectual frames. It can be thought that a more flexible 
approach may take the place of prejudices and stereotypes in individuals who are aware of the fact that though things and behaviors are the same, they are named and interpreted differently.

From the aspect of learning and teaching, that adults, who are generally in the teaching position, become the ones who learn and are taught, can ensure the recognition of the fact that everyone has something to learn from others. This is the most important point tried to be emphasized with this study. The reflection of the principle "learning is an activity based on co-operation" emphasized in Social Interaction Theory can be seen in the interactions between children and parents.

Foreign language learning is one of the most effective methods to open different ways of thinking. For this, it is important to start foreign language learning at early ages, and to develop and implement teaching methods and approaches appropriate for children. Increasing the efforts to improve the points that are thought to affect learning negatively and providing necessary information to all stakeholders can contribute to obtaining the desired efficiency in foreign language teaching just as in all areas of education.

Quantitative success oriented teaching is an impeding factor for permanent learning in foreign language learning, as with any learning. The adoption of acquisition based understanding in teaching foreign language to children rather than quantitative success oriented teaching is important for permanent and sustainable learning. It is thought that planning of interesting activities for out-of-school and non-school days by the educational planners would be beneficial for making foreign language teaching at schools continuous. For this, broadcasts and publications on foreign language teaching to children can be carried out with the cooperation of official television channels and national press. It is recommended that parents and foreign language teachers develop utterances and behaviors enhancing the desire for learning in cooperation so as to avoid the understanding of "I do not understand foreign languages" become permanent in children.

\section{References:-}

1. Acat, B. \&Demiral, S. (2002). Türkiye'deYabancıDilÖğretimindeMotivasyonKaynaklarıveSorunları. KuramveUygulamadaEğitim Yönetimi. Issue: 31, (pp. 312-329)

2. Adıgüzel, A. (2009). YenilenenillköğretimProgramınınUygulanmasıSürecindeKarşılaşılanSorunlar. Mehmet AkifErsoyÜniversitesiEğitimFakültesiDergisi, 9(17), (pp. 77- 94)

3. Akpınar, B. \& Aydın, K. (2009). ÇokDuyulu (Multisensory) YabancıDilÖğretimi, TubavBilimDergisi, Volume: 2, Issue: 1, (pp. 99-106)

4. Ambrose, S., Bridges, M., DiPietro, M., Lovett, M. \& Norman, M. (2010). How Learning Works: Seven Research-Based Principles for Smart Teaching - chapter 3. San Francisco: John Wiley \& Sons.

5. Anşin, S. (2006). ÇocuklardaYabancıDilÖğretimi, D. Ü. ZiyaGökalpĔ̈itimFakültesiDergisi 6, (pp. 9-20)

6. Balcı, A. (2005). SosyalBilimlerdeAraştırma. Ankara: Pegem A Yayıncılık.

7. Berger, K. S. \& Thompson, R. A. (1995). The Developing Person. Through Childhood and Adolescence, U.S.A.: Worth Publishers Inc.

8. Berguno, G., \& Bowler, D. M. (2004). Communicative interactions, knowledge of a second language, and theory of mind in young children. Journal of Genetic Psychology, 165(i), (pp. 293-309)

9. Brett, A. G. (2004). Seven hundred reasons for studying languages. Retrieved from: https://www.llas.ac.uk/ on: 03.04.2015.

10. Butzkam, W. \&Butzkam, J. (2004). Wie Kinder sprechen lernen. Kindliche Entwicklung und Sprachlichkeit des Menschen. Tübingen: Franke,

11. Chandler, M. A. (2014 October 31). Parents want elementary pupils to learn foreign languages - but where? The Washington Post.

12. Cumming-Potvin, W., Renshaw, P., \& van Kraayenoord, C. E. (2003). Scaffolding and bilingual shared reading experiences: Promoting primary school students" learning and development. Australian Journal of Language and Literacy, 26(2), (pp. 54-68)

13. Demirel, Ö. (2003). ELT Methodology. Ankara: Pegem A Yayıncıllk.

14. Doğanay, A. \&Tok, Ş. (2010). Öğretimdeçağdaşyaklaşımlar. Doğanay, A. (edt.) ÖğretimillkeveYöntemleri, (pp. 215-277)

15. Europäische Kommisyon. (2012). Schlüsselzahlen zum Sprachenlernen an den Schulen in Europa. Brüssel: Eurydice.

16. Gibitz, U. (2002). Fremdsprachen Lernen und Lehren Heute. Wir Deutschlehrer. Kamerun: Goethe Institut Yaonde. 
17. Karasar, N. (2003). BilimselAraştırmaYöntemi (12. Baskı). Ankara: Nobel YayınDağıtım.

18. Katz, L. G. (1993). Dispositions: Definitions and implications for early childhood practice. Champaign, IL: ERIC Clearinghouse on Elementary and Early Childhood Education (ED360104).

19. Kühne, N. (2003). Wie Kinder Sprache Lernen - Grundlagen, Strategien, Bildungschancen. Darmstadt: Wissenschaftliche Buchgeselschaft\& Primus Verlag,

20. Lee, W. R. (1979). Language Teaching Games and Contests. Oxford: Oxford University Press.

21. Lightbown, P. M., \&Spada, N. (2006). How languages are learned (3. Basim). Oxford: Oxford University Press.

22. Maurice, K. (1998). Laugh While Learning Another Language: Techniques That Are Functional and Funny. English Teaching Forum.

23. Memiş, M.R. \&Erdem, M.D. (2013). YabancıDilÖğretimindeKullanılanYöntemler, KullanımÖzellikleriVeEleştiriler, Turkish Studies - International Periodical for The Languages, Literature And History Of Turkish or Turkic. Volume 8/9, P. 297-318, Ankara-Turkey

24. Nunan, D. (2001). Designing tasks for the communicative classroom, 15. Printing, Cambridge University Press, USA

25. Oksaar, E. (1987). Spracherwerb im Vorschulalter. Einführung in die Pädolinguistik, 2. Erweiterte Auflage, Stuttgart u.a.: Kohlhammer.

26. Poloma, M. M. (1993). ÇăğdaşSosyolojiKuramları, (Çev: Hayriye Erbaş). Ankara: GündoğanYayıncılık.

27. Richards, J. C. \& Rodgers, T. S. (2001). Approaches and Methods in Language Teaching, Second Edition, Cambridge Language Teaching Library, Cambridge University Press, USA.

28. Rogoff, B. \& Morelli, G. (1989). Perspectives on Children's Development from Cultural Psychology, American Psychologist, 44: 343- 348.

29. Roopnarine, J.L. (2011). Cultural variations in beliefs about play, parent-child play and children's play: Meaning for children development. In A Pellegrini (Ed.) Oxford handbook on play. New York: Oxford University Press.

30. Stewart, J. H. (2005). Foreign Language Study in Elementary Schools: Benefits and Implications for Achievement in Reading and Math. Early Childhood Education Journal, Vol. 33, No. 1, DOi: 10.1007/s 10643005-0015-5.

31. Wieman, C. (2013). Motivating Learning, Science Education Initiative. Retrieved from: http://www.cwsei.ubc.ca/resources/files/Motivating-Learning_CWSEI.pdf on: 15.03.2018.

32. Weimer, M. (2002). Lerner-centered teaching. San Francisco: Jossey-Bass.

33. Wesche, M.B., \&Skehan, P. (2002). Communicative, task-based, and content-based language instruction. R. B. Kaplan (Haz.), The Oxford handbook of applied linguistics (pp. 227-228). Oxford, UK: Oxford University Press. 